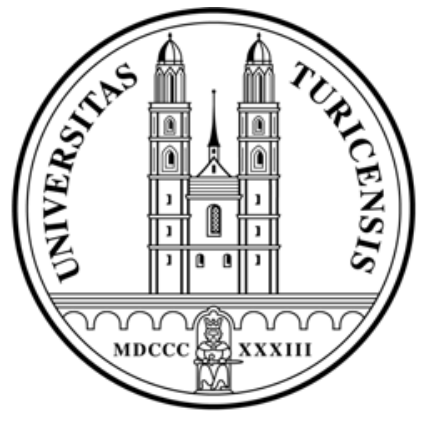

Institute for Empirical Research in Economics

University of Zurich

Working Paper Series

ISSN 1424-0459

Published in: Journal for Institutional Innovation,

Development and Transition, Vol. 7, 2003, 42-59

Working Paper No. 165

Direct Democracy for Transition Countries

Bruno S. Frey

July 2003 


\title{
DIRECT DEMOCRACY FOR TRANSITION COUNTRIES
}

\author{
by \\ Bruno S. Frey* \\ (University of Zurich)
}

(this version: 21 July 2003)

\begin{abstract}
Theoretical arguments and empirical evidence are advanced to bolster the claim that direct political participation via referenda and initiatives constitutes an advanced form of democracy with beneficial effects on Transition Countries.

Direct democracy raises trust and honesty and improves social outcomes. Per capita incomes and subjective well-being are raised.

Standard arguments against direct democracy (citizens' incompetence and lacking interest, danger of manipulation and emotionality, hindering progress and destroying civil rights, high cost) are rejected.

Elements of direct democracy can be introduced at the national and local levels, and then proceeding further. Citizens should have the right to govern this process.
\end{abstract}

JEL classification: $\mathrm{H} 0, \mathrm{P} 2$

Key words: Direct democracy, referenda, initiatives, political participation, citizens, democratic rights, transition economies

\footnotetext{
* The author is Professor of Economics at the Institute for Empirical Economic Research, University of Zurich, and Director of CREMA - Center for Research in Economics, Management and the Arts. e-mail: bsfrey@iew.unizh.ch. I am grateful for the intensive discussion at the Collegium Budapest project on "Honesty and Trust", in particular to Bruce Ackerman, Russell Hardin, Cynthia Horne, Margaret Levi, Margit Osterloh, Bo Rothstein, Karoly Takacs, Alexandra Vacroux and Laszlo Zsolnai. Alois Stutzer went through a earlier version of the manuscript and provided excellent suggestions for improvement. I specially thank Susan Rose-Ackerman for carefully checking the manuscript and making suggestions for improvement.
} 


\section{Democracy, Social Capital and Economic Development}

Democracy affects social capital and social capital affects the economic development of transition economies: this is the basic proposition made in this paper. It moreover argues that direct democracy, by inducing civic participation, is particularly effective in raising trust between citizens and government. Thus it strongly contributes to social capital ${ }^{1}$. The paper suggests that extended direct participation rights by the citizens via popular referenda and initiatives is a desirable goal. Consider the two causal relationships involved in turn: (A) The effect of direct democracy on trust, and (B) The effect of social capital on economic development.

\section{A. The Effect of Direct Democracy on Social Capital}

\section{What is Direct Democracy?}

There are many different meanings, conceptions and also misunderstandings of "direct democracy". The following two aspects of the way the term "direct democracy" is used here are crucial":

\section{a. Referenda and Initiatives as Additional Rights}

Direct democracy (or, more precisely, semi-direct democracy) does not substitute for parliament, government, courts and all the other features known in representative democracies. Instead, it shifts the final right to determine issues to the citizens. The extent of direct participation rights may vary, but they always include constitutional changes normally by an obligatory referendum. Optional referenda and initiatives (to put issues on the political agenda) require a predetermined number of signatures by the citizens before they can take place.

In a historical perspective, three main stages of democracy may be distinguished:

- Classical democracy first developed in Athens and other Greek city states. Participation rights were restricted to male citizens therefore excluding a large part of the population, and extended only over the small area of a town. Yet the principles of democracy still revered and used today were developed there.

- The French Revolution extended democracy to a large area and population. The principle of representation made is possible to introduce indirect political participation to the nation state.

- Direct democracy combines these two earlier types of democracy by giving the right to decide on particular issues to every citizen. The extreme (classical) form of having citizens decide on every

\footnotetext{
${ }^{1}$ There may, of course, be other types of democracy leading to similar beneficial results, say some form of discursive democracy; see Dryzek 1990. But as will be argued these types do not necessarily exclude each other. A case in point is that direct democracy strongly induces a particularly effective way of political discourse.

2 See e.g. Magleby 1984, Cronin 1989, Butler and Ranney 1994, Frey 1994, Kirchgaessner, Feld and Savioz 1999.
} 
issue is nowhere practiced today but the extent of issues on which citizens may vote varies widely among countries. Over the period 1990 to 2000, no less than 405 popular referenda on the national level were recorded (see Gross and Kaufmann 2002, Butler and Ranney 1994). More than half took place in Europe, namely 248 (and again half of them in Switzerland); 78 in America, 37 in Africa, 26 in Asia and 16 in Oceania ${ }^{3}$. In the decade before (1980 to 1990) there were only 129 national referenda. There is a very large number of popular referenda on lower levels of government. In 2001, for instance, there were almost 10,000 local referenda in the United States, or in the German state of Bavaria 500. In Switzerland there are thousands of referenda at all three levels of government: local, cantonal and federal. Up to August 2002, issues of European integration led to no less than 30 national referenda.

Most of the new constitutions adopted by the Central and Eastern European Transition Economies were approved by a popular referendum. Almost all of them include elements of direct democracy. The most intensive use was made in Lithuania. Between 1991 and 1996 there were 17 national referenda on such important issues as independence, the withdrawal of Russian troops, and the new constitution. Important steps towards direct democracy have also been made in Slovenia, Latvia, Slovakia, Hungary and Poland. A more extensive account of the situation in Transition Economies is provided in the Appendix.

Many important decisions in most democracies are not taken by letting the general electorate decide. Nowhere (except in Switzerland and Liechtenstein) are popular referenda used in a regular and systematic way at the national level. In the United States, despite its many local popular decisions, and its frequent use in some States such as California and Oregon, there is no referendum at the national level. Many important decisions shaping a country's fate for decades to come are not subject to a popular referendum. A telling example is Germany. The citizens had no say either with respect to the conditions for the integration (if at all) of the former GDR or the dumping of the Deutsche Mark and introduction of the Euro. Directly democratic decisions are in many cases not taken seriously by the politicians in power. A revealing example is the Irish vote on the Nice Treaty of the European Union. The citizen rejected its acceptance in June 2001. Before the second vote on the issue due to take place in August 2002 EU politicians made it clear that they would go ahead with the Treaty's program, irrespective of whether the Irish vote would be positive or negative (though unanimity within the EU is required).

\footnotetext{
${ }^{3}$ Some of these referenda certainly do not meet the requirement of leaving the (final) decision on an issue to the general electorate but rather are plebiscites, i.e. votes in which the government wants the support by the population for a decision already taken.
} 


\section{b. Referenda and Other Forms of Consultation of Citizens}

Referenda are a right given to the citizens by the constitution. Government and parliament are bound by these rights: they are not free to ask the opinion of the citizens only when they please. This distinguishes referenda from plebiscites undertaken by governments to ex post sanction a decision already taken by them. The citizens thus are not asked to decide an issue but only to express support for the government. Referenda also fundamentally differ from opinion surveys which are on the spot views of people without any consequence for the government: they can follow or disregard the results. In contrast, when citizens have taken a decision in a referendum, the constitution obliges the government to put the corresponding policy into practice.

\section{Two Types of Trust between Citizens and Government}

The institution of direct democracy establishes two quite different concepts of trust between the citizens and government.

\section{a. Citizens' Low Trust in Government}

Past experiences of citizens with oppressive, authoritarian governments are often vivid. The politicians in these governments showed no regard for the populations' wishes and demands but rather autocratically imposed their own preferences. Moreover, they used the public means for their private benefit ${ }^{4}$. The citizens were well aware that the classe politique materially exploited them. Only a limited part of the available resources was used to improve the situation of the population; much was used for the benefit of the ruling (communist) class and its followers as well as for projects that enhance national prestige and for military purposes. Consequently, the citizens have low trust in government ${ }^{5}$.

\section{b. Politicians' Low Trust in Citizens}

The decision-makers in all political areas, be it the executive, the legislative or the legal branch, find it difficult or even impossible to imagine that the citizens are motivated and capable of participating in politics. This is a general feature of all such decision-makers - once they are in power. The reason is simple: they do not want to share power with the population. Many opposition parties and opposition movements strongly favor citizen participation in politics, but once they get

\footnotetext{
${ }^{4}$ Politicians in democracies are also tempted to engage in private rent seeking but there are constitutional safeguards miting these possibilities such as the rule of law (including human rights and property rights) as well as party competition and courts. Rent seeking is generally discussed in Tullock 1967, Buchanan and Tullock 1980, Tollison 1982.

5 There is a large literature discussion citizens' trust in government, see e.g. recently the collections in Braithwaite and Levi 1998, Warren 1999, Cook 2000, as well as Levi 1988, 1998a, 1998b, Rose-Ackerman 2001, Hardin 2002, and specifically for post-communist societies Mishler and Rose 1997.
} 
into power, they very quickly see things differently and no longer want to give up part of their power.

Politicians in Transition Economies are also influenced by past experiences. In authoritarian states politicians encountered little open opposition or resistance. Citizens rightly feared the negative consequences and hid their true views (Kuran 1995). As a general strategy, it made more sense to circumvent the official sector, and to rely on informal channels, in particular the family and friends. Many politicians therefore thought - and perhaps liked to fool themselves - that the population was indifferent to their decisions. This belief was only rarely shaken when the dissatisfaction of the population exploded in the form of uprisings as in the GDR in 1952, in Hungary in 1956, and in Czechoslovakia in 1968. But once these revolts were crushed, the politicians were rarely confronted with much open opposition. Many politicians in today's Transitions Economies are therefore not used to be faced with, and to democratically deal with, different views. They only learn slowly that in a democracy differences in views are perfectly legitimate and provide an important source of information helping them to do well in a democratic system in which politics consists in the peaceful competition of ideas.

\section{Direct Democracy Raises Social Capital}

When citizens have political participation rights extending to issues of content social capital is raised in regard to both aspects discussed above:

(a) Citizens have a higher trust in government because the politicians are constitutionally restricted in their actions. They must behave more closely in accordance to citizens' wishes.

(b) Politicians exhibit higher trust in the citizens by granting them the right to codetermine in current political decision-making.

Section II of this paper presents strong empirical evidence in favor of these statements.

\section{A. Social Capital and Economic Development}

There exists a considerable literature discussing the effects of social capital on economic development ${ }^{6}$. These results are consistent with econometric analyses for a large cross-section of countries in which a large number of determinants potentially influencing economic development (such as capital investment, infrastructure, education etc.) are simultaneously taken into account ${ }^{7}$. Research undertaken over the last decades has demonstrated the crucial importance of social capital for economies in transition as well as for developing countries. Particularly prominent is the work

\footnotetext{
6 Recent examples are Dasgupta and Serageldin 1999, Paldam and Svendsen 2000a, 2000b, Glaeser, Laibson and Sacerdote 2000, OECD 2001..
} 
by Putnam $(1993,2000)$ who showed in a comparison between Southern and Northern Italy, and then for the United States, that social capital is a crucial element for economic development ${ }^{8}$.

To privatize and to deregulate is certainly not sufficient to spark economic development. What is also needed is social capital in the form of mutual trust and honesty ${ }^{9}$. A market economy needs strong political institutions setting the rules governing private transactions. In the Transition Economies the state may still be intervening in many areas of life, but at the same time it is weak in the sense that it is not able to guarantee the rule of the law. In particular, property rights are not well established and private contracts are enforced only at high cost, or not at all. The state is weak because it is no longer dictatorial but trust has not (yet) emerged. This holds both for the trust of citizens in the state and the trust of political actors in the citizens. In the perception of the people, and in reality, democracy is not (yet) working well. As a result there is widespread illegality and crime. An important reflection of this lawlessness is the large size of the shadow or underground economy ${ }^{10}$.

Table 1 indicates that the shadow economy has been estimated to be much larger in the Transition Economies.

Table 1: Size of the Shadow Economy, 2000/2001. Percent of GDP

\begin{tabular}{lllc}
\hline \multicolumn{2}{c}{$\begin{array}{c}\text { Central Europe } \\
\text { (selection) }\end{array}$} & \multicolumn{2}{c}{$\begin{array}{c}\text { Western European Countries } \\
\text { (selection) }\end{array}$} \\
\hline Slovenia & 27 & Switzerland & 9 \\
Poland & 27 & Ireland & 16 \\
Czech Republic & 18 & Sweden & 19 \\
Hungary & 24 & Netherlands & 13 \\
Romania & 33 & Finland & 18 \\
Bulgaria & 36 & Norway & 19 \\
Belarus & 47 & Belgium & 22 \\
Ukraine & 51 & Britain & 13
\end{tabular}

\footnotetext{
7 E.g. Barro 1997, Knack and Keefer 1997, and for a survey Moesen and Cherchye 2002.

8 More recently see e.g. Hjollund, Svendsen and Paldam 2001.

9 See e.g. Mansbridge 1994, Fukuyama 1995, Kramer and Tyler 1996, Zak and Knack 1998, Glaeser, Laibson, Scheinkman and Soutter 1999

${ }^{10}$ See Schneider and Enste 2000, Frey and Schneider 2001.
} 


\begin{tabular}{|c|c|c|c|}
\hline & & Italy & 27 \\
\hline & & Spain & 23 \\
\hline & & France & 15 \\
\hline & & Austria & 11 \\
\hline Average & 33 & Average & 17 \\
\hline Median & 27 & Median & $16 / 18$ \\
\hline
\end{tabular}

Note: Percent of GDP

Data: source Schneider 2002

On average, the shadow economies in developed Western countries is about half the size (17 percent of GDP) of that in European Transition Economies (33 percent). While some Western countries have quite large underground economies (in particular Italy, Spain and Belgium), in Transition Economies the smallest such sectors start at that level while in some of them (in particular Belarus and Ukraine) the shadow economy is up to half the officially measured GDP. Another important consequence of lacking social capital is dishonesty and corruption. As this consequence has been treated extensively elsewhere ${ }^{11}$ it is not further discussed here.

\section{Propositions}

This paper deals with the relationship between direct democracy and social capital in the form of trust and honesty, and economic conditions in transition economies.

The general proposition is:

Direct democracy is a social innovation with economically beneficial effects on

Transition Economies.

The more specific propositions are:

1. Direct democracy systematically raises trust and honesty (social capital);

1. High trust and social capital contribute to economic growth.

1. If the first two propositions hold, direct democracy systematically improves social outcomes (economic conditions and subjective well-being);

1. The standard arguments against direct democracy (citizens' incompetence and lacking interest, danger of manipulation and emotionality, hindering progress and destroying civil rights, high cost) are not convincing;

1. Directly democratic decisions require time and opportunity for intensive discussion;

\footnotetext{
11 See Rose-Ackerman 1999, 2001, Mauro 1995.
} 
1. If (3) and (4) hold, Transition Economies can and should introduce elements of direct democracy beginning with the national and the local level, and then proceeding further;

1. If (3) and (4) hold, citizens should have the right to govern the process of introducing popular initiatives and referenda.

The remainder of the paper is an effort to convince the reader that propositions 3 and 4 are generally valid and hence that it is worth taking the time and trouble to make directly democratic processes a reality in the Transition Economies.s

\section{Procedure}

Section II discusses the main features of direct democracy. Section III compiles the econometric evidence about the consequences on the economy and society of direct democracy. The possibilities of introducing elements of direct democracy in Transition Economies are considered in section IV. The last section draws conclusions. The Appendix presents a short survey on the institutions of direct democracy already existing in Transition Economies.

\section{Features of Direct Democracy}

On 6 December 1992 the Swiss citizens voted in a referendum whether their country should join the European Economic Space. This date was preceded by a heated discussion in the public media (radio, television and newspapers) as well as among individuals. Political parties, interest groups and individual politicians were also strongly engaged in the discussion. The position of the Swiss political, economic and cultural leadership was as unanimous as rarely before: the national and cantonal governments and parliaments, the political parties, the pressure groups involving both the producers and the trade unions, academics, artists and sports people, and whoever else "matters" in a society all ${ }^{12}$ supported Switzerland's entry into the European Economic Space. The popular referendum witnessed an extraordinarily high rate of participation ( 78 percent while the average between 1985 and 1992 is 42 percent only). 50.3 percent of the population, and 16 out of the 23 cantons ${ }^{13}$ were against the proposal. Thus, the proposition was rejected by the citizens.

Such a clear-cut clash between what the 'classe politique' and what the population wants is no rare event in Switzerland. It illustrates an idea central to the rational choice analysis of politics (Public

\footnotetext{
${ }^{12}$ The major exception was the Zurich section of a bourgeois party (Schweizerische Volkspartei) but the delegate of this party in the Swiss national government composed of seven members of equal rank (Bundesrat) strongly supported entry.

${ }^{13}$ Both a majority of the population and of the cantons is required for adopting the proposal.
} 
Choice $^{14}$ ) as well as to Constitutional Economics ${ }^{15}$, namely that the politicians do not necessarily pursue the interests of the population at large.

The discussion of the characteristics of direct democracy focuses on four aspects to be discussed in the following subsections:

(A) Major deviations between the wishes of the 'classe politique' and the population are a common event in all representative democracies but they are not observable because the issue is not tested via referenda.

(B) A referendum should not be looked at as simply a decision taken at given point of time but the discussion taking place before, and the political adjustments undertaken thereafter, form an essential part of it.

(C) The institution of referenda is closely linked to federalism. In a unitary national government, referenda tend to degenerate to plebiscites i.e. to a vote of confidence for the politicians in power who initiate it whenever they expect it to be advantageous to them.

(D) Many arguments have routinely been advanced against referenda. But it will be argued that these arguments are invalid.

\section{A. Referendum against Politicians' Cartel}

Persons acting within the confines of the political system have incentives to exploit it to their advantage. It need not be assumed at all that politicians are 'bad', or any worse than other persons, but they tend - as anyone else - to opportunism. They endeavor to further their own interest consisting in material wealth but also in recognition and prestige.

In a democracy, politicians can use three main actions to gain benefits at citizens' cost, or to 'exploit' the general population ${ }^{16}$ :

\footnotetext{
${ }^{14}$ The state of knowledge is well summarized in Mueller (1989). It contains a large number of references to the relevant literature.

Public Choice is part of the economic approach to social problems (Becker 1976, Kirchgaessner 1991, Frey 1999, 2001, Lazear 2000) ranging from education (Blaug 1968/69), environment (e.g. Cropper and Oates 1992), family (Becker 1981), history (North 1981), women (Blau and Ferber 1992), sport (Goff and Tollison 1991), art (Frey and Pommerehne 1989, Frey 2000), and many other areas.

${ }^{15}$ See Buchanan and Tullock (1962), and many subsequent works by Buchanan (e.g. 1975, 1977, 1991) and by Brennan and Buchanan (1980, 1985). Relevant is also the literature on rent seeking as developed by Tullock (1967), Buchanan, Tollison and Tullock (1980), and surveyed by Tollison (1982).
} 
(1) Politicians may take decisions they know to deviate from the voters' preferences. Political actors may so act because they have an ideology of their own or because they reap material and nonmaterial advantages by so acting. For instance, politicians systematically prefer direct interventions into the economy over employing the price system because regulations generally allow them to derive larger rents.

(2) Politicians secure themselves excessive privileges in the form of direct income for themselves or their parties, pensions and fringe benefits (cars, houses etc.)

(3) Citizens' exploitation may finally take the form of corruption, i.e. direct payments for special services provided to payers but not to others.

Politicians have a common interest to protect, and if possible to extend, these rents, i.e. they have an incentive to form a cartel against the ordinary citizens. There is, however, a public good problem involved: an individual politician has an incentive to break out if such action finds favor with the electorate. But this happens rarely. The politicians in most countries form a close-knit group of people separated from the rest of the population. They mainly have contacts with each other so that the social disapproval of those few who dare to break out of the cartel imposes major costs on the "defectors". Moreover, the cartel is administrated by the leaders of the parties. Defecting politicians are quickly and effectively sanctioned by the other members of the cartel, for instance, by restricting access to parliamentary positions (in particular powerful commissions) or by reducing the monetary support provided by the parties. An individual politician is forced to form part of the cartel because the leadership of the party has many means available to control him or her, including forced resignation.

All the actors involved, in particular the voters, are well aware that there are strong and ubiquitous incentives for the politicians to form a cartel and to exploit the voters. In reaction, one finds three quite different forms of institutions in democratic constitutions designed to check such action:

(1) Rules prohibiting the (excessive) appropriation of rents by the politicians, the most stringent ones being against corruption. Obviously, such rules are only effective if they cannot easily be circumvented and if they are well enforced. Such provisions are completely useless against the first stated type of exploitation, namely the systematic deviation from citizens' preferences. As the privileges accorded by the politicians to themselves are of an extremely varied kind and are made difficult to detect, experience shows that politicians' rent seeking can thereby by scarcely prevented. With respect to corruption, only the most blatant cases are ever detected. It must be

\footnotetext{
${ }^{16}$ Empirical evidence for the extent of rent appropriations by the politicians are provided e.g. for Germany by von
} 
concluded that while such rules are of some use, they certainly are not able to prevent citizens' exploitation to any significant degree.

(2) The establishment of special courts with the task of preventing citizens' exploitation. All democratic countries know some institution of courts of accounts but it may well be shown that they fulfill their role only to a small extent. They are obviously the less effective, the more directly they depend on the politicians they are supposed to control. In this respect it does not help much if the members of the court of accounts are elected and must answer to the parliament. Even courts of accounts formally independent of government and parliament have little incentive and possibility to check the exploitation of the citizens by the voters. This applies particularly to the deviation from citizens' preferences. Courts of accounts necessarily have to focus on the formal correctness of politicians' and administrators' behavior. This may tend to widen the gap between what politicians provide and what the population wishes.

(3) In representative democracies the competition between parties is the classical institution to prevent politicians' to pursue their own goals at the population's cost. Constitutions know various devices to further competition and to make a coalition between the politicians more difficult. One is the division of power between the executive, legislative and jurisdictional branches, another is the establishment of two houses of parliament. Because of the many types of interactions existing, and the well- defined gains to be expected, these devices are rather ineffective to check the interests of the 'classe politique'.

An important constitutional device to stimulate competition between parties is to facilitate the entry of new parties into the political system. While this certainly forces the established parties in a democracy to better care for the population's wishes and to be more careful with respect to privileges and corruption, the effect tends to be short-lived. The previous outsiders quickly realize that many advantages are to be gained by tolerating the politicians' cartel, and even more to participate in it. The experience in many countries supports this theoretical proposition (e.g. with respect to the 'Green' parties in Western European countries who first fought against the political establishment but within surprisingly little time have learnt to take advantage of the taxpayers' money).

These arguments strongly suggest that neither constitutional rules, nor courts, nor party competition are successful in reducing the exploitation of the general population by the politicians. It is not argued, of course, that the constitutional features elaborated are useless but that they do not provide a sufficient safeguard against politicians' rent seeking. 
A referendum in which all the citizens have the possibility to participate meets the crucial requirement that it gives decision-power to people outside the politicians' cartel. The individuals deciding are not integrated into the 'classe politique' and they evade the control by politicians. In an initiative, the demands are explicitly directed against the political establishment represented in parliament and government. Optional and obligatory referenda serve more a controlling function as they overrule, if successful, the decisions taken by the executive and legislative.

A popular referendum (in the wide sense) can only serve its purpose if the 'classe politique' cannot block it. In many countries, the supreme court has the power to decide whether a referendum is admissable. While the criteria are purely formal in fact the members of the court (who form part of the 'classe politique') have considerable incentives to forbid referenda threatening the position of the politicians' cartel, often using vague concepts based on what they consider to be the 'raison d'état'. In other countries, almost no such possibility exists, and therefore issues are brought to the vote which meet an almost unanimous opposition by the politicians.

The politicians are well aware that the institution of popular referendum severely restricts their possibility to pursue their own goals. They are therefore basically inclined to oppose direct democratic elements.

\section{B. Referendum as a Process}

It would be mistaken to consider a referendum just to be a vote. Indeed, two important stages before and after the vote must be considered.

\section{The Pre-Referendum Process}

The constitutional setting determines to a large extent what issues are put on the political agenda, and what are prevented to appear. In representative democracies, politicians are often very skillful not to let problems be discussed in the democratically legitimized institutions which are to their disadvantage. As has been shown both theoretically and empirically, agenda setting power has a significant effect on vote outcomes ${ }^{17}$.

\footnotetext{
${ }^{17}$ See Romer and Rosenthal (1978, 1979) for Oregon school budget referenda, and Weingast and Moran (1983) for congressional Committees. The two groups of researchers do not consider the general role of referenda in agenda setting but concentrate on its effect on bureaucratic decisions. Our emphasis is on its role as a means to break the politicians' cartel.
} 
An important feature of referenda is the discussion process stimulated among the citizens, and between politicians and citizens ${ }^{18}$. Pre-referendum discussion may be interpreted as an exchange of arguments among equal persons taking place under well-defined rules. This institutionalized discussion meets various conditions of the "ideal discourse process" as envisaged by Habermas (1983). The relevance of discussion for politics induces citizens to participate depending on how important the issue in question is considered to be. The experience of Switzerland shows indeed that some referenda motivate intensive and far-reaching discussions (such as the referenda on whether to join the European Economic Space with a participation rate of almost 80 percent compared to an average of roughly 40 percent). Other referenda considered to be of little importance by the voters engender little discussion and low participation rates (down to 25 percent). This variability in the intensity of discussion and participation overrides the much studied "paradox of voting" (Tullock 1967, Riker and Ordeshook 1968).

The main function of the pre-referendum process is certainly to raise the level of information of the participants. Benz and Stutzer (2002) have shown that the level of information of the citizens is indeed the higher the more extensive the political participation rights of the citizens is in the various Swiss cantons. It may, moreover, be hypothesized that the exchange of arguments also forms the participants' preferences. What matters most is that this preference formation can be influenced, but cannot be controlled, by the 'classe politique'.

\section{Post-Referendum Adjustments}

In a referendum a political decision is formally taken but this does not necessarily mean that the politicians and the public administration take the appropriate action to implement it. The more legitimate the constitution is taken to be in a political system, the higher are the costs of not following it. The politicians may also be induced to so act by the threat of not being reelected by the voters, but ultimately the extent of implementation depends on whether the constitutional rules are voluntarily obeyed by the persons in power.

The question of which side gets a majority in a referendum is not the only thing that matters. A referendum also clearly reveals how the population feels and where and how large the minorities are. Groups dissenting from the majority are identified; their preferences become visible and become part of the political process (see Gerber 1997). This makes it more likely that particular

\footnotetext{
${ }^{18}$ The essential role of discussion in direct democracy is more fully discussed in Frey and Kirchgaessner 1993, Bohnet and Frey 1994. For democracy in general see Dryzek 1990.
} 
parties start to champion their cause in order to win additional support, and for referenda in particular regions to take place.

Switzerland provides again a suitable example. In 1989 a popular initiative demanded that the Swiss Army be completely dismantled. This by many Swiss was considered as an attack against one of the almost "sacred" institutions of the country. The classe politique was solidly against the initiative, and the generals threatened that they would retire if the initiative was not overwhelmingly rejected (they spoke of a share of no-votes between 80 and 90 percent). The referendum outcome was a surprise to all because one third of the voters (and a majority among the young voters eligible for military service) voted for the dissolution of the army. After a short period of shock, several parties suggested changes in the army which were put into reality within a short time - changes which before the referendum were considered to be impossible to achieve by everyone.

\section{Referenda and Federalism}

The institution of citizens directly deciding an issue and the decentralization of decision making are closely connected. On the one hand, federalism is an alternative means for better fulfillment of the voters' preferences: individuals tend to leave dissatisfying jurisdictions while they are attracted to those caring for the population's preferences at low cost. The possibility to vote with one's feet (Tiebout 1956; see also Buchanan 1965, Hirschman 1970) tends to undermine regional cartels by politicians, provided, of course, the persons concerned have political rights.

Federalism is at the same time a prerequisite for effective referenda rather than a substitute. In small communities, much knowledge needed for informed political decision-making is impacted in every-day life. The citizens are well aware about the benefits and costs of particular public programs. Moreover, as taxpayers they have to carry the burden, provided there exists a sufficient amount of fiscal equivalence (Olson 1969, 1986).

\section{Common Arguments against Direct Democracy}

Referenda can hardly be considered a generally accepted institution. Not surprisingly, the members of the 'classe politique' are quick to raise strong objections. They realize that referenda constitute a 
threat to their power by limiting their rent seeking potential. Many intellectuals also reject referenda with a variety of arguments. The basic reason is that they consider themselves to be better judges of what is "good" for the people than the citizens themselves. They tend to see themselves in the role of a 'philosopher-king' determining what 'social welfare' is. Consequently, they prefer decisionmaking systems where they have a larger say. Thus, their opposition against referenda is due to the same interests as the one against the market (see Stigler 1984). The following statement by a political scientist illustrates the widespread feeling among intellectuals that referendum democracy 'reduces governmental efficiency of performance and the capacity to innovate' (Hertig 1984, pp. 254-5; my translation). This is, however, a purely technocratic view of efficiency. It disregards the inclination of politicians to deviate from citizens' preferences, and to engage in rent seeking for their own benefit.

The following ten arguments are raised against direct democracy:

\section{Citizens fail to understand the complex issues}

The average voter, so it is argued, is not well informed and educated so that he or she cannot reasonably be let to determine political issues; this is the task of a specialized group, the politicians, who represent the voters.

This view can be refuted in various respects:

First of all, it is inconsistent to trust citizens to be able to choose between parties and politicians in elections but not between issues in referenda. If anything, the former choice is more difficult as one must form expectations about politicians' choices on issues forthcoming in the future.

Secondly, the voters need not have any detailed knowledge about the issues at stake, Rather, they must only grasp the main questions involved. These main questions are not of a technical nature but involve decisions of principle which a voter is equally qualified to take as are the politicians.

Thirdly, the general intelligence and qualification of politicians should not be overrated. They can hardly be considered to be much and consistently superior to other people. Moreover, the average member of parliament has little choice; he or she is normally forced to vote according to what the party superiors and some few specialists have decided before.

Finally, a number of institutions have emerged in direct democracies helping citizens to take reasoned decisions. The parties and interest groups make suggestions of how to decide which the citizens may consider. Even more importantly, the discourse in the pre-referendum stage brings the main aspects forth and puts them into perspective. 


\section{Citizens have little interest in participating}

Participation in initiatives and referenda often is quite low. Sometimes, only few eligible voters go to the polls. It is therefrom concluded that citizens are not interested in the issues to be decided. This is, however, a mistaken conclusion for three reasons:

Firstly, the vote participation is not always so low. When the citizens feel that the issue is important the vote participation strongly rises. Switzerland provides a good example of this variability: While average participation over all issues at the federal level is around 45 percent, it can be as little as 25 percent. But sometimes it rises up to 80 percent and more as was the case when in 1992 the Swiss citizens had to decide whether they wanted to join the European Economic Area.

Secondly, high vote participation is not necessarily a good thing. Citizens are perfectly rational not to participate when they find the issues unimportant or when they are undecided. It could even be argued that it is socially beneficial that citizens do not participate under these conditions but rather leave the decision to those for whom the issue matters. Vote participation then reflects citizens' preference intensities which makes the vote socially more valuable.

Thirdly, it would be naive to think that freely chosen vote participation in parliaments is much different from how citizens behave with respect to popular referenda. Today's members of parliament are highly specialized and seriously consider the pros and cons of few issues. In the case of all other issues they (have to) follow the dictate of the party leadership, i.e. do not cast a voluntary vote. This is reflected in the often extremely low participation in parliamentary session. The members of parliament have to be herded together from the lobby or their offices to cast the dictated vote.

\section{Citizens are easy to manipulate}

Financially potent parties and pressure groups are better able to start initiatives and to engage in referendum propaganda than are poor and non-organized interests. This cannot be denied. However, the perspective is mistaken because it takes an absolute stance: it is always true that the rich and well-organized groups wield more power. The crucial question is whether they have more or less power in a direct than in a representative democracy. It is well known that well-organized and financed pressure groups exert considerable power over the politicians sitting in parliament and in government. It may even be argued that it is cheaper to influence the small number of legislators and government politicians than the total electorate.

\section{Citizens are prone to decide emotionally}


Voters are often supposed to be unduly influenced by emotional considerations. Again, this charge must be considered in a comparative perspective. There is little reason to believe that politicians are less subject to emotions. After all, parliaments are known to have highly emotional debates, sometimes even erupting into fist fights. For that reason, many parliaments have formal procedures to consider a proposal two or even three times, with considerable time elapsing in between. The same holds for popular referenda. Before taking the vote there must be time for intensive discussion in which the various sides of a question can be brought up. This strongly increases the chance of a decision dominated by rational aspects ${ }^{19}$.

\section{There are too many referenda confusing the voters.}

When the citizens have to simultaneously decide over a great many issues (in California, for instance, the voters often have to deal with forty or even more propositions) they focus on a few visible issues. The decisions on all the other issues then is haphazard and looks rationality.

This is indeed a situation to be avoided. However, the number of referenda put to the vote can be steered by the number of signatures required for an initiative or optional referendum. If the number of issues to be decided about gets too large, the number of signatures required can be raised. Such decision should be taken by a constitutional referendum to prevent that the classe politique fixes such high a number of signatures that referenda become improbable.

\section{Political leadership is impossible}

Politicians are sometimes supposed to take unpopular decisions. An example would be a restrictive fiscal policy when the budget deficit is growing too high or when inflation reaches high rates. Such policy pays off only over the medium or even long term. It is therefore claimed to be opposed by the population as it imposes hardships. It is argued that such unpopular policies would be impossible in a direct democracy.

This conclusion does, however, not necessarily hold. In a direct democracy the politicians are forced to explain their policies to the citizens. If they can give good reasons why they propose to undertake such a seemingly unpopular policy the citizens will not oppose it. There are many examples for Switzerland that the citizens are prepared to support policies burdening them provided

\footnotetext{
${ }^{19}$ In July 2002, the German Bundestag debated (and rejected) a proposal to introduce elements of direct democracy at the federal level. For fear of emotional decisions, the introduction of the death penalty was from the very beginning excluded as a subject for a referendum. This overlooks that an extensive discussion among the citizens, and with experts and politicians, brings to the fore all sides of the issue. A purely emotional decision is unlikely to occur. Moreover, many countries using executions follow the representative principle (the United States being an example) while the country with most extensive direct democracy (Switzerland) prohibits the death sentence.
} 
the politicians make an effort to explain why the sacrifice is necessary to improve the situation over the long term.

\section{Referenda are inadequate for major issues}

As the voters are taken to be badly educated and ill informed, subject to manipulation and to emotional decisions it is often argued that referenda should be admitted for small and unimportant issues, only. In contrast, issues of great consequence - such as changes in the constitution - should be left to the professional politicians.

The opposite position makes more sense. Major issues can be reduced to the essential content. Evaluation then is not a matter of (scientific) expertise but of value judgements. Following methodological individualism, only the citizens may be the final judges when it comes to preferences, and a substitution by representatives is, at best, a second best solution. As the politicians have a systematic incentive to deviate from the voters' preferences, a substitution leads to biased outcomes.

\section{Referenda hinder progress}

To ask the population to take a decision is often rejected because it is argued that the 'ordinary citizens' do not like changes and that they prevent the adoption of 'bold, new ideas'.

It may well be true that many new propositions are rejected in referenda but this does not mean that this constitutes a disadvantage. That proposals contain new ideas is no proof of their quality. Indeed, the citizens are right in rejecting them when they are in favor of the 'classe politique'. The concept of 'bold, new' solutions is not rarely the result of technocratic thinking and of a planning mentality. They strengthen the politicians' and bureaucrats' position but need not be in the voters' interest.

Referenda are a well-proven procedure to break dead locks in societal decision making and in this sense are progressive. There are cases in which an issue is difficult to resolve in parliament and by the government, and where a referendum helps to clear the issue. An example is the demands by regions for more independence. These demands are often accompanied by considerable violence and bloodshed. The Basque country is just one of many cases. In a direct democracy such heated issues may be brought to a solution acceptable to a large majority. In Switzerland, for instance, the secession of the Jura from the canton Bern was achieved by undertaking a number of referenda. While some minor violence took place, the issue was settled with much less strife and bloodshed than normally occurs in representative democracies, let alone autocratic systems. 


\section{Referenda destroy civil rights}

One of the fundamental problems of democracy is the "tyrrany of the majority". This danger is seen to be particularly acute in the case of referenda where the will of the majority is unrestricted. As a result, civil rights may be thwarted. But this is not necessarily the case. Most importantly, if there are economic, social and political cross cleavages no part of the citizens always is in the majority and therefore will be careful not to antagonize other social groups. Empirically, some evidence for the suppression of civil rights has been found in local and state ballots in the United States (Gamble 1997) but there is also contrary evidence for the USA and Switzerland (Cronin 1989, Frey and Goette 1998).

\section{Referenda are expensive}

The last argument against referenda is the alleged high cost of undertaking it administratively. It is argued that parliamentary decisions are much less expensive and should therefore be favored.

There are two reasons why this reasoning is fallacious.

Firstly, referenda are not expensive compared to the large cost of entertaining a professional parliament with its accompanying party system (see e.g. von Arnim 1988 for Germany). As in a direct democracy the last say is with the citizens, less money needs to be spent on parliament and the parties. Moreover, the administrative cost of referenda are not high because several propositions can be bundled at one weekend, and citizens can be asked to actively participate in organizing the vote and counting the votes. While the citizens drafted suffer some opportunity cost, such a participation has the advantage of getting them more directly involved in governing their state which tends to raise their sense for citizens' duties.

Secondly, the administrative cost of running referenda is immaterial compared to their major advantage, namely to significantly reduce the deviation of political decisions from individual preferences. That this is indeed the case has been established by careful econometric investigations (for a survey see Schneider 1992, see also Steunenberg 1992).

\section{Consequences of Direct Democracy}

Over the last few years substantial empirical evidence has been collected about the effects on the economy and society of having the institution of referenda. As only few countries consistently use direct democracy for political decisions, the research has concentrated on two countries, the United States and Switzerland. In both of them the analysis proceeds by identifying different degrees of 
participation rights between states and cantons, and between communes. The results show a consistent effect on important economic and social variables of direct democracy. These analyses are well summarized in a recent book (Kirchgaessner, Feld and Savioz 1999). Some results are of special relevance for Transition Economies:

(1) Political outcomes correspond more closely to the voters' preferences the more directly democratic they are (Pommerehne 1990).

(2) The growth of public expenditure is more strongly determined by demand factors (i.e. by the citizens' willingness to pay) than by supply factors (in particular by the politicians' and bureaucrats' own interest) (Pommerehne and Kirchgaessner 1991).

(3) Public supply is the less costly, the more direct the democratic institutions are (Pommerehne 1978).

(4) Tax morale is the higher, the more extended the citizens' participation rights (Torgler 2001, 2003). "Tax morale" measured by response to the response to the question:" Is it always justified (never justified, sometimes justified) to cheat on taxes?" gathered by the World Value Survey over a cross-section of countries.

(5) Tax evasion is the lower, the more direct participation rights the citizens have (Frey 1997).

(6) Per capita incomes in cantons with more strongly developed direct participation possibilities of the citizens (all other factors being equal) are significantly higher than in cantons with less developed forms of direct participation (Feld and Savioz 1997). This result is, of course, of special importance for transition economies which want to catch up with more developed economies.

(7) Inhabitants of cantons with more extended participation rights experience higher self-reported subjective well being than the population in cantons with fewer directly democratic institutions (Frey and Stutzer 1999, 2002a). Direct democracy systematically raises happiness.

In order to clarify the methodology with which these empirical results have been gained, the effect of the extent of citizens' direct participation rights on subjective well-being - which may be most surprising to some readers - is sketched here (for a more complete discussion see Frey and Stutzer $1999,2002 \mathrm{a})^{20}$.

The dependent variable is self-reported subjective well-being, or happiness, measured by careful surveys among representative individuals. The following question is asked: "Overall, how happy do

\footnotetext{
20 Studies of subjective well being in transition economies are e.g. Ravaillon and Loshin (2001) and several contributions in the special issue of the Journal of Happiness Studies (2001)
} 
you feel with the life you lead?" The answers may rank from 1 ("extremely unhappy") to 10 ("extremely happy"). Careful research especially by psychologists suggests that the answers to this question are reliable, valid and consistent. ${ }^{21}$

These individual happiness indicators are explained by a large number of explanatory variables (depending on the specific estimation equation, up to 30 variables). The most important are

- socio-economic determinants, such as age, sex, marital status, number of children and educational level,

- economic determinants, in particular income, employment status, rate of inflation,

- institutional determinants. In our context the crucial factor is the extent of direct political participation rights in the various Swiss cantons. They vary considerably. In some cantons (e.g. Kanto Basel Landschaft) they are extensive, in other (e.g. Geneva) they are more restricted, e.g. only some types of issues but not other may put to a referendum.

All these data refer to the cross-section of the 26 cantons of Switzerland. The overall number of observations is 6,000 . The econometric estimation technique employed is non-linear multivariate probit as the dependent variable is discontinuous and restricted. The results yield a statistically significant and large positive effect on individual well-being of the extent of political participation rights.

This result can be attributed to two factors:

(a) The political outcomes are closer to the wishes of the population, and the public services are produced more efficiently. The population is therefore more satisfied with the government. This result is consistent with the more partial results reported above, e.g. that public provision corresponds more closely to individual preferences or that per capita income is higher.

(b) The citizens value the direct participation possibilities in their own right thus producing procedural utility $^{22}$. This result was derived by comparing the life satisfaction of the Swiss (who do have participation rights) with that of the foreigners (who have no political participation rights), keeping all other influences constant.

\footnotetext{
21 Questions of reliability, validity and consistency of self-reported measures of subjective well-being, life satisfaction or happiness are discussed in Frey and Stutzer 2002a, b, Easterlin 2002, Holländer 2001, Lane 2000, Diener and Suh 2000, Kahneman, Diener and Schwarz 1999, Veenhoven 1997. Graham and Pettinato 2002 and Hayo and Siebert 2002 devote special emphasis on transition economies.
}

\footnotetext{
22 See the work by Tyler 1990 dealing with procedural justice. A general survey of procedural utility is provided in
} Frey, Benz and Stutzer 2003. 
This discussion reveals that there exists considerable empirical evidence of the beneficial effects of direct democracy on social capital and on political outcomes. Most results refer to Switzerland because this is the country where referenda and initiatives are the most often used. But there are similar results for some of the American States, in particular California, Oregon and Washington (see the careful discussion in Kirchgaessner, Feld and Savioz 1999). While it is certainly true that conditions differ in other countries. Bit the existing evidence suggests at least that such beneficial effects exist and that they constitute one possibility to raise trust in government in transition economies.

\section{Introducing Direct Democracy in Transition Economies}

Any attempt to introduce popular initiatives and referenda is faced with a basic problem of interdependence. Social capital is both a precondition and consequence of direct democracy.

\section{Precondition}

- It is impossible to successfully run directly democratic institutions where there is no adequate basis in society. One condition under which direct democracy ${ }^{23}$ works well is when there are strong cross-cutting cleavages (e.g. with respect to per capita income, religion, and culture or language). This guarantees that it is not always the same group of persons that finds itself in the minority and therefore feels exploited. As has also been emphasized, the citizens must have sufficient trust in the politicians that they put the referenda decisions into reality, and the politicians must have trust that the citizens take reasonable decisions when voting on issues. This trust must develop over time and cannot simply be instilled from outside. Therefore, the "grand" solution of jumping from a representative democracy straight into a fully developed direct democracy is both unrealistic and undesirable. Rather, direct participation rights for the citizens should be gradually introduced ${ }^{24}$ so that a learning process of the citizens, parliament and government the can take place.

\section{Consequence}

- As has been documented above the use of initiatives and referenda by the citizens is a major factor raising social capital especially in the form of the trust citizens have in the government. Direct democracy thus helps to create the necessary conditions for its own functioning provided the learning effect indeed takes place.

\footnotetext{
${ }^{23}$ But this condition is not specific to only direct democracies but holds for all types of democracy.
} 


\section{A. Gradual Procedure}

There are five ways in which directly democratic rights can be gradually introduced in transition economies.

\section{Decision level}

Direct democratic elements can be restricted by initially granting them only on a particular level of the state.

One possibility is to start at the local level, giving citizens the right to launch initiatives and vote in referenda in political communes. This allows the citizens to benefit from everyday or impacted information to form a reasoned opinion. Moreover, the issues are often of immediate relevance to the population. But this procedure makes only sense if the political communes have a sufficient amount of autonomy. Preferably, they should be able to decide on both taxes and public expenditures. As documented by Swianiewicz (2001) there are quite extensive referenda rights in some Transition Economies, particularly in Hungary and Poland.

Another possibility is to start at the national level, when major issues are at stake. This has indeed happened in several Transition Economies where the decision of whether to join the European Union has been relegated to the citizens as a whole. As these decisions are of crucial importance, the citizens are well aware of their relevance and will certainly be inclined to participate in the vote.

\section{Issue Domain}

Some questions can be excluded from direct voting for fear of "irresponsible" or "uncontrollable" outcomes. One could restrict the domain in the following way:

- Basic parts of the constitution such as those referring to human, political and civil rights can be excluded ${ }^{25}$.

- Supposedly sensitive issues may be removed from citizens' voting. This may refer to problems relating to particular minorities, ethnic or religious groups, but also to, for example, the death penalty (as in Germany).

- Issues that are thought to be beyond the competence of the citizens. This may, for instance, be assumed to hold for economic problems such as taxation. (In Germany, the recent proposal to introduce national referenda excluded from the very beginning tax issues).

\footnotetext{
24 To gradually introduce direct democratic elements in a political system dominated by the government may, however, induce the risk that the government on purpose undermines it functioning in order to "demonstrate" to the citizens that it cannot work. I owe this point to Bo Rothstein.

${ }^{25}$ Such restriction may make sense also in fully developed direct democracies but it should be noted that in Switzerland that is not the case. But it should be immediately added that the Swiss voters have had not inclination to fiddle with such basic rights.
} 


\section{Time}

The referendum process may be shaped by requiring a sufficient amount of time to pass between the start of an initiative or referendum process, the vote and the decision becoming effective. This is a move towards the constitutional idea (e.g. Mueller 1996) of putting people behind the veil of uncertainty, and therefore inducing them to take a more "objective" position.

A more innovative idea is to proceed as (many) parliaments do, namely to have a first, second and sometimes even a third reading of a law. In a direct democracy, one could first have an informative vote, and after sufficient time to allow a discussion of the outcome, a decisive vote.

\section{Size of majority}

Passing a proposal in a popular vote may require a supermajority, for instance two thirds of the participants. Alternatively, one may require a simple majority but of the whole electorate, including those abstaining. Such quorums exist, in many Transition Economies (see the Appendix). In several of them, referenda received a majority of the vote cast, but not of the electorate.

A strong restriction on popular initiatives and optional referenda is the number of signatures required. A balance between having a low required number (and therefore many referenda) and a high required number (and therewith excluding citizens) is needed.

\section{Co-determination}

The citizens' decision may only become effective if it is supported by a corresponding vote in the parliament (and perhaps even in the two houses). Another possibility would be to accord a veto right to either the citizens or to parliament. One may also consider a double majority in the form of the popular vote and in the regions (cantons or states). This latter requirement applies, for instance, in Switzerland where both the majority of all the Swiss voters, and the majority of the cantons must approve a constitutional referendum.

\section{B. Governing Gradual Introduction}

The restrictions just discussed constitute a considerable danger for direct democracy. Most importantly, the restrictions introduced may stay for good. In the case of several of the restrictions this would amount to a destruction of the whole idea of citizens' participation in political decisionmaking. The institutions of direct democracy cannot develop their strength. The outcome of politics would not correspond more closely to citizens' preferences than under a traditional representative system. Moreover, the citizens are unable to learn well the special features of direct democracy. If, 
for instance, only very unimportant issues are put to the vote, or if the number of signatures required for an initiative or optional referendum is all too high, the citizens cannot experience the advantages of direct democracy. On the other hand, the politicians can always claim that they gave direct democracy a chance but that it did not work. In the case of tight restrictions a vicious circle may possibly develop. The way popular participation is introduced leads to unsatisfactory results and experiences providing the opponents of direct democracy (in particular the politicians in power) with a good reason to introduce even more severe restrictions. Under these circumstances direct democracy can, of course, not work.

The limitations on the levels at which elements of direct democracy are to be introduced make most sense. The rights for initiatives and referenda should first be introduced at the local level and at the same time at the national level, and perhaps only later at the regional level. At the local level, the citizens tend to be well informed about the issues in questions, while at the national level the decisions to be taken are of obvious importance. As the Appendix shows, these are indeed the levels where direct democratic elements have been introduced in several Transition Economies, though only to a limited degree. But it is noteworthy, that the decision most strongly affecting national sovereignty and the future development of the economy and society, accession to the European Union, will be subjected to a popular referendum in most, if not all Transition Countries.

The crucial question is who governs the step-wise introduction of directly democratic instruments. Several political actors may be in charge:

\section{The government.}

As has already been pointed out repeatedly, the politicians in power find popular participation rights do be against their interests as their decision power is reduced. Governments therefore tend to block or to undermine direct democracy whenever possible, especially in periods between election times. To grant governments the right to determine the process of introducing direct democracy therefore means thwarting it.

\section{The parliament.}

The similar situation as for government applies to legislators and parties. It may be that some members of parliament who are outside positions of power favor direct citizen participation. In contrast, the powerful members of parliament resent sharing power with an outside group, the ordinary citizens, and therefore make every effort to oppose elements of direct democracy. 
Parties may also instrumentalize institutions of direct participation for their own short term factional interests. In several transition countries, particularly Hungary, the experience with referenda is therefore considered in a rather negative light by the citizens. They tend to look at referenda as just another way to gain advantages in politically motivated fights. The essential feature of referenda, namely to enable citizens to participate in deciding between issues of content, is thereby lost. For these reasons it is not advisable to give parties and parliament the right to govern the introduction of direct democracy.

\section{The constitutional assembly.}

Ideally, its members are not directly involved in current politics, they take a more objective stance. They do not have to fear a reduction in their own power if direct democracy is introduced in the future. In reality, however, a considerable part of the members are likely to belong to the "classe politique". They served in the past, currently do, or hope to do so in the future, in political decision making. In all cases they tend to oppose popular participation in political decision-making.

It may be argued that in most transition economies the period in which such a constitutional assembly was possible has passed. On the other hand, the European Union - which Hungary and other transition economies will soon join - has summoned a Constitutional Convention in which the basic rules governing the relationship between the citizens and the Union is to be discussed.

\section{The citizens.}

They are the only actors not part of the 'classe politique', and they are the main beneficiaries of direct democracy. It can therefore be expected that if the citizens have the right to govern the stepwise introduction of the right to undertake popular initiatives and referenda the outcome will be most favorable. This is consistent with the conclusions drawn by an observer of local affairs for the Transition Economies in the Czech Republic, Hungary, Poland and Slovakia: „..although public opinion on local government is usually better than on central government institutions, there is a relatively modest satisfaction level regarding local government activity. This goes together with limited feelings of inclusion in local public affairs. The solution for increasing this limited level of satisfaction with local governments' activities might be to intensify communication between local authorities and the general public" (Swianiewicz 2001:29). The most effective way to intensify communication is to strengthen citiens' direct political participation rights.

\section{Conclusions}


The paper advances the proposition:

Direct political participation rights via referenda and initiatives constitute an advanced form of democracy with potentially beneficial effects on Transition Countries.

Theoretical arguments and empirical evidence have been used to bolster this claim.

It has been shown specifically that

1. Direct democracy systematically raises trust and honesty. Both are crucial elements of social capital;

2. Direct democracy systematically improves social outcomes. Economic conditions, in particular per capita incomes and subjective well-being (citizens' happiness) are raised;

3. The standard arguments against direct democracy (citizens' incompetence and lacking interest, danger of manipulation and emotionality, hindering progress and destroying civil rights, high cost) are not convincing;

4. Direct democratic decisions require the time and opportunity for intensive discussion;

5. Elements of direct democracy can be introduced in transition countries beginning with the national and the local level, and then proceeding further;

6. A gradual introduction of features of direct democracy is well possible and advisable because this supports a necessary learning process;

7. Citizens should have the right to govern the process of introducing popular initiatives and referenda.

The paper does not argue that direct democracy is a necessary or the only institution capable of raising trust in government in transition economies (or elsewhere). There are many other fruitful possibilities in need of exploring. The goal of the paper is reached if the reader has become aware that the institutions of direct democracy have had beneficial effects on social capital and political outcomes in some countries and that it presents a worthwhile direction in which democracies can be further developed. 


\section{Appendix}

\section{Elements of Direct Democracy in Transition Economies ${ }^{26}$.}

\section{Slovenia.}

Citizens have a non-binding initiative right but in practice they can subject all laws passed by parliament to popular approval via facultative referenda. Since 1990, four national referenda have been undertaken. There is a 50 percent participation requirement and popular referenda are restricted to laws.

\section{Latvia.}

10 percent of the electorate can initiate a change of the constitution or a new law and a parliamentary decision can be subjected to referendum. Certain issues are excluded and there is a 50 percent participation quorum. There will be referendum on accession to NATO and the EU.

\section{Lithuania.}

There is an obligatory referendum for constitutional changes, a popular initiative and a facultative referendum. Between 1991 and 1996 there were 16 national referenda. The participation quorum is 50 percent. There will be a referendum on accession to NATO and the EU.

\section{Slovakia.}

This country knows a binding initiative right. The participation quorum is 50 percent and there is moreover 50 percent approval quorum.

\section{Hungary}

There is an initiative right for laws. 200,000 signatures collected within four months gives the right to launch a popular referendum. A wide-ranging list of exemptions and the right of courts to intervene strongly restrict these rights. In 1997, the government reduced the 50 percent participation quorum to 25 percent for the NATO and future referenda such as the accession to the EU.

\section{Poland.}

Two reform referenda in 1987 helped to bring down Communist control. However, when in 1996 600,000 citizens gave their signatures to demand a referendum on privatization, the government 
used its constitutional veto right to deny the citizens' demand (though the constitutional requirement is only 500,000 signatures). High participation quorums at the local level result in referendums often being declared invalid.

\section{Estonia.}

There is an obligatory constitutional referendum to be invoked for the decision to entry NATO and the EU. Otherwise the citizens have no rights of initiative or referendum.

\section{Czech Republic.}

This country is one of the few in the world never having had a referendum. However, a new law of initiative and referendum is being worked out for the forthcoming decision on entry into the EU.

\section{Rumania.}

There is a right for constitutional referenda and for petitioning a parliamentary debate. A referendum has a 50 percent participation quorum.

\section{Bulgaria.}

There are no direct democratic rights at the national of local level. Only the accession to the EU will be put to a popular vote.

\footnotetext{
${ }^{26}$ The appendix follows closely the survey presented in Gross and Kaufmann (2002). See also the extensive evidence presented in Swianciewicz (2001).
} 


\section{References}

Barro, Robert J. (1997). Determinants of Economic Growth. A Cross-Country Empirical Study. Cambridge, MA and London: MIT Press.

Becker, Gary S. (1976). The Economic Approach to Human Behavior. Chicago: Chicago University Press.

Becker, Gary S. (1981). A Treatise on the Family. Cambridge, MA: Harvard University Press.

Benz, Matthias and Alois Stutzer (2002). Are Voters Better Informed When They Have a Larger Say in Politics? Working Paper No. 119, Institute for Empirical Economic Research, University of Zurich.

Blau, Francine D. and Marianne A. Ferber (1992). Women's Work, Women's Lives: A Comparative

Economic Perspective. In: Hilda Kahne and Janet Z. Giele (eds) Women's work and women's lives: The continuing struggle worldwide. Boulder and Oxford: Westview Press: $28-44$.

Blaug, Mark (1968/69). Economics of Education. Vol 1. and Vol 2. Harmondsworth: Penguin.

Bohnet, Iris and Bruno S. Frey (1994). Direct-Democratic Rules: The Role of Discussion. Kyklos 47 (3): $341-354$.

Braithwaite, Valerie and Margaret Levi (eds) (1998). Trust and Governance. New York: Russell Sage.

Brennan, Geoffrey and James M. Buchanan (1980). The Power to Tax. Analytical Foundations of a Fiscal Constitution. Cambridge: Cambridge University Press.

Brennan, Geoffrey and James M. Buchanan (1985). The Reason of Rules. Constitutional Political Economy. Cambridge: Cambridge University Press.

Buchanan, James M. (1965). An Economic Theory of Clubs. Economica 32 (1): 1-14.

Buchanan, James M. (1975). The Limits of Liberty: Between Anarchy and Leviathan. Chicago: University of Chicago Press.

Buchanan, James M. (1977). Freedom in Constitutional Contract. Perspective of a Political Economist. College Station: Texas, A\&M University Press.

Buchanan, James M. (1991). Constitutional Economics. Oxford: Basil Blackwell.

Buchanan, James M., Robert N. Tollison and Gordon Tullock (eds) (1980). Toward a Theory of the Rent-Seeking Society. College Station, Texas: Texas A\&M University Press.

Buchanan, James M. and Gordon Tullock (1962). The Calculus of Consent. Logical Foundations of Constitutional Democracy. Ann Arbor: University of Michigan Press.

Butler, David and Austin Ranney (eds) (1994). Referendums around the World. The Growing Use of Direct Democracy. Washington, D.C.: AEI Press. 
Cook, Karin S. (ed) (2000). Trust in Society. Washington D.C.: Russell Sage .

Cronin, Thomas E. (1989). Direct Democracy. The Politics of Initiative, Referendum and Recall. Cambridge, MA: Harvard University Press.

Cropper, Maureen L. and Wallace E. Oates (1992). Environmental Economics: A Survey. Journal of Economic Literature 30 (June): 675-740. .

Dasgupta, Partha and J. Serageldin (eds) (1999). Social Capital. A Multifaceted Perspective. Washington: World Bank.

Diener, Ed and Eunkook M. Suh (eds) (2000). Culture and Subjective Well-Being. Cambridge, MA: MIT Press.

Dryzek, John S. (1990). Discursive Democracy: Politics, Policy and Political Science. Cambridge: Cambridge University Press.

Easterlin, Richard A. (ed.) (2002). Happiness in Economics. International Library of Critical Writings in Economics 142. Celtenham, UK, and Northampton, MA, USA: Edward Elgar.

Feld, Lars P. and Marcel R. Savioz (1997). Direct Democracy Matters for Economic Performance: An Empirical Investigation. Kyklos 50 (4): 507-538.

Frey, Bruno S. (1994). Direct Democracy: Politico-Economic Lessons from Swiss Experience. American Economic Review 84 (2): 338-348.

Frey, Bruno S. (1997). A Constitution for Knaves Crowds Out Civic Virtues. Economic Journal 107 (443): 1043-1053.

Frey, Bruno S. (1999). Economics as a Science of Human Behaviour. 2nd rev. and extended ed., Boston and Dordrecht: Kluwer.

Frey, Bruno S. (2000). Arts and Economics. Heidelberg and New York: Springer Verlag.

Frey, Bruno S. (2001). Inspiring Economics: Human Motivation in Political Economy. Cheltenham, UK and Northampton, MA: Edward Elgar.

Frey, Bruno S., Matthias Benz and Alois Stutzer (2003). Procedural Utility: Not Only What, but also How Matters. Journal of Theoretical and Institutional Economics, forthcoming.

Frey, Bruno S. and Lorenz Goette (1998). Does The Popular Vote Destroy Civil Rights? American Journal of Political Science 42 (4): 1343-1348.

Frey, Bruno S. and Gebhard Kirchgaessner (1993). Diskursethik, Politische Ökonomie und Volksabstimmungen. Analyse und Kritik 15 (2): 129-149.

Frey, Bruno S. and Werner W. Pommerehne (1989). Muses and Markets: Explorations in the Economics of the Arts. 1990 reprint, Oxford: Blackwell. 
Frey, Bruno S. and Friedrich Schneider (2001). Informal and Underground Economy. In: Orley Ashenfelter (ed.) International Encyclopedia of the Social and Behavioral Sciences. Amsterdam: Elsevier Science Publishing Company.

Frey, Bruno S. and Alois Stutzer (1999). Happiness, Economy and Institutions. Economic Journal 110 (446): 243-253.

Frey, Bruno S. and Alois Stutzer (2002a). Happiness and Economics. How the Economy and Institutions Affect Human Well-Being. Princeton, NJ: Princeton University Press.

Frey, Bruno S. and Alois Stutzer (2002b). What Can Economists Learn from Happiness Research? Journal of Economic Literature 40 (2): 402 - 435.

Fukuyama, Francis (1995). Trust: The Social Virtues and the Creation of Property. New York: Free Press.

Gamble, Barbara S. (1997). Putting Civil Rights to a Popular Vote. American Journal of Political Science 41: 245-269.

Gerber, Elisabeth R. (1997). The Populist Paradox: Interest Groups and the Promise of Direct Legislation. Princeton: Princeton University Press.

Glaeser, Edward, David Laibson and Bruce Sacerdote (2000). The Economic Approach to Social Capital. NBER Working Paper 7728.

Glaeser, Edward, David Laibson, Jose A. Scheinkman and Christine L. Soutter (2000). Measuring Trust. Quarterly Journal of Economics 115: 811-846.

Goff, Brian and Robert D. Tollison (eds) (1991). Sportometrics. College Station: Texas A\&M University Press.

Graham, Carol and Stefano Pettinato (2002). Happiness and Hardship. Washington D.C.: Brookings Institution Press.

Gross, Andreas and Bruno Kaufmann (2002). IRI Europe Country Index on Citizen Lawmaking 2002. Amsterdam: IRI (Initiative and Referendum Insititute Europe).

Habermas, Jürgen (1983). Diskursethik - Notizen zu einem Begründungsprozess. In: Jürgen Habermas (ed.) Moralbewusstsein und kommunikatives Handeln. Frankfurt: Suhrkamp: 53-125.

Hardin, Russell (2002). Trust and Trustworthiness. New York: Russell Sage.

Hjolland, Lene, Gert Tinggaard Svendsen and Martin Paldam (2001). Social Capital in Russia and Denmark: A Comparative Study. $5^{\text {th }}$ International Conference on Institutions in Transition, Otocek, Slovenia, 13-14 July, 2000.

Hayo, Bernd and Wolfgang Seifert (2002). Subjective Economic Well-being in Eastern Europe. Discussion Paper, University Essen, No. 120 . 
Hertig, Hans Peter (1984). Volksabstimmungen. In: Ulrich Klöti (ed.) Manuel Système Politique de la Suisse. Vol. 2. Bern: Haupt: 247-277.

Hirschman, Albert O. (1970). Exit, Voice and Loyalty. Cambridge, MA: Harvard University Press.

Holländer, Heinz (2001). On the Validity of Utility Statements. Journal of Economic Behavior and Organization 45 (3): 227-249.

Kahneman, Daniel, Ed Diener and Norbert Schwarz (eds) (1999). Well-Being: The Foundations of Hedonic Psychology. New York: Russell Sage Foundation.

Kirchgaessner, Gebhard (1991). Homo Oeconomicus: Das ökonomische Modell individuellen Verhaltens und seine Anwendung in den Wirtschafts- und Sozialwissenschaften. Tübingen: Mohr (Siebeck).

Kirchgaessner, Gebhard, Lars Feld and Marcel R. Savioz (1999). Die direkte Demokratie: Modern, erfolgreich, entwicklungs- und exportfähig. Basel et al.: Helbing and Lichtenhahn/ Vahlen/ Beck.

Knack, Stephen and Philip Keefer (1997). Does Social Capital have an Economic Payoff? A Crosscountry Investigation. Quarterly Journal of Economics : 1251 - 1288.

Kramer, Roderick M. and Tom R. Tyler (1996). Trust in Organizations. Thousand Oaks: Sage.

Kuran, Timur (1995). Private Truth, Public Lies: The Social Consequences of Preference Falsification. Cambridge, MA: Harvard University Press.

Lane, Robert E. (2000). The Loss of Happiness in Market Economies. New Haven and London: Yale University Press.

Lazear, Edward (2000). Economic Imperialism. Quarterly Journal of Economics 115 (Feb.): 99146.

Levi, Margaret (1988). Of Rule and Revenue. Berkeley: Univeristy of California Press.

Levi, Margaret (1998a). Consent, Dissent and Patriotism. Cambridge: Cambridge University Press.

Levi, Margaret (1998b). A State of Trust. In: Braithwaite, Valerie and Margaret Levi (eds) (1998). Trust and Governance. New York: Russell Sage.

Magleby, David B. (1984). Direct Legislation. Voting on Ballot Propositions in the United States. Baltimore and London: The Johns Hopkins University.

Mansbridge, Jane (1994). Public Spirit in Political Systems. In : Henry J. Aaron, Thomas E. Mann and Timothy Taylor (eds), Values and Public Policy. Washington D.C.: Brookings Institution: 146-172.

Mauro, P. Corruption and Growth. Quarterly Journal of Economics 110: 681-712. 
Mishler, William and Richard Rose (1997). Trust, Distrust and Skepticism: Popular Evaluations of Civil and Political Institutions in Post-Communist Societies. Journal of Politics 59: 418451.

Moesen, Wim and Laurens Cherchye (2002). Social Capital and Economic Performance: What Have We Learnt? Mimeo, Center for Economic Studies, Catholic University of Leuven.

Mueller, Dennis C. (1989). Public Choice II. 2nd ed., Cambridge: Cambridge University Press.

Mueller, Dennis C. (1996). Constitutional Democracy. New York: Oxford University Press.

North, Douglass C. (1981). Structure and Change in Economic History. New York: Norton.

OECD (2001). The Well-Being of Nations. The Role of Human and Social Capital. Paris: Centre for Educational Research and Planning. OECD.

Olson, Mancur (1969). The Principle of "Fiscal Equivalence": The Division of Responsibilities among Different Levels of Government. American Economic Review 59 (2): 479-487.

Olson, Mancur (1982). The Rise and Decline of Nations: Economic Growth, Stagflation, and Social Rigidities. New Haven: Yale University Press.

Olson, Mancur (1986). Towards a More General Theory of Governmental Structure. American Economic Review 76 (2): 120-125.

Paldam, Martin (2000). Social Capital : One or Many? Definition and Measurement. Journal of Economic Surveys 14: 629-653.

Paldam, Martin and Gert Tinggaard Svendsen (2000a). An essay on social capital: looking for the fire behind the smoke. European Journal of Political Economy 16: 339-366.

Paldam, Martin and Gert Tinggaard Svendsen (2000b). Missing social capital and the transition in Eastern Europe. Journal of Institutional Innovation, Development and Transition.......

Pommerehne, Werner W. (1978). Institutional Approaches to Public Expenditure: Empirical Evidence from Swiss Municipalities. Journal of Public Economics 9 (2): 225-280.

Pommerehne, Werner W. (1990). The Empirical Relevance of Comparative Institutional Analysis. European Economic Review 34 (2-3): 458-469.

Pommerehne, Werner W. and Hannelore Weck-Hannemann (1996). Tax rates, tax administration and income tax evasion. Public Choice 88: 161-170.

Pommerehne, Werner W. and Gebhard Kirchgässner (1991). Neuere Ansätze zur Erklärung der langfristigen Entwicklung der Staatsausgaben. Ein Überblick. Wirtschaftswissenschaftliches Studium 9 (20).

Putnam, Robert D. (1993). Making Democracy Work. Princeton: Princeton University Press.

Putnam, Robert D. (2000). Bowling Alone: The Collapse and Revival of American Community. New York, NY: Simon and Schuster. 
Ravaillon, Martin and Michael Lokshin (2001). Identifying Welfare Effects from Subjective Questions. Economica 68: 335-357.

Riker, William H. and Peter C. Ordeshook (1973). An Introduction to Positive Political Theory. Englewood Cliffs, NJ: Prentice Hall.

Romer, Thomas and Howard Rosenthal (1978). Political Resource Allocation, Controlled Agendas, and the Status Quo. Public Choice 33 (4): 27-43.

Romer, Thomas and Howard Rosenthal (1982). Median Voters or Budget Maximizers: Evidence from School Expenditure Referenda. Economic Inquiry 20 (4): 556-78.

Rose, Richard, T. W. Mishler and C. Haerpfer (1998). Democracy and its Alternatives. Understanding Post-Communist Societies. Baltimore: John Hopkins University Press.

Rose-Ackerman, Susan (1999). Corruption and Government: Causes, Consequences and Reform.Cambridge: Cambridge University Press.

Rose-Ackerman, Susan (2001). Trust and Honesty in Post-socialist Economies. Kyklos 54: 415-444.

Schneider, Friedrich and Dominik Enste (2000). Increasing Shadow Economy All Over the World Fiction or Reality? Journal of Economic Literature 38 (1): 77-114.

Slemrod, Joel (2000). Trust in Public Finance. Mimeo, Department of Economics, University of Michigan.

Steunenberg, Bernard (1992). Referendum, Initiative, and Veto Power: Budgetary Decision Making in Local Government. Kyklos 45: 501-529.

Stigler, George J. (1984). The Intellectual and the Marketplace. Cambridge, MA: Harvard University Press.

Swianiewicz, Pawel (2001). Public Perception of Local Governments. Budapest: Local Government and Public Service Reform Initiative.

Tiebout, Charles M. (1956). A Pure Theory of Local Expenditure. Journal of Political Economy 64 (5): 416-424.

Tollison, Robert D. (1982). Rent Seeking: A Survey. Kyklos 35 (4): 575-602.

Tullock, Gordon (1967). The Welfare Costs of Tariff, Monopolies and Theft. Western European Journal 5 (June): 224-232.

Torgler, Benno (2001) What Do We Know About Tax Morale and Tax Compliance? RISEC, International Review of Economics and Business 9: 395-419.

Torgler, Benno (2003). Tax Morale, Rule Governed Behaviour and Trust. Constitutional Political Economy 14: 119-140.

Tyler, Tom (1990). Why People Obey the Law. New Haven: Yale University Press. 
Veenhoven, Ruut (1997). Progres dans la comprehension du bonheur. Revue Quebecoise de Psychologie 18: 29-74.

Von Armin, Hans Herbert (1988) .XXXXXXXXXXXX

Warren, Mark (ed) (1999). Democracy and Trust. Cambridge: Cambridge University Press

Weingast, Barry R. and Mark J. Moran (1983). Bureaucratic Discretion or Congressional Control? Regulatory Policymaking by the Federal Trade Commission. Journal of Political Economy 91 (5): 765-800.

World Values Study Group (1994). World Values Survey 1991-1993. Ann Arbor: Inter-University Consortium for Political and Social Research.

World Values Study Group (1998). World Values Survey 1995-1997. Ann Arbor: Inter-University Consortium for Political and Social Research.

Zak, P.J. and Steven Knack (1998) Trust and Growth. Economic Journal 111: 295-321. 